\title{
Labor motivation of agricultural workers in the context of modern trends in personnel management
}

\author{
Tatiana Gaponenko ${ }^{1, *}$, Safura Muradova ${ }^{2}$, and Victoria Litvinova ${ }^{3}$ \\ ${ }^{1}$ Don State Technical University, 1, pl. Gagarina, 344002, Rostov-on-Don, Russia \\ ${ }^{2}$ Southern University (Institute of Management, Business and Law), 33A/47, Mikhaila Nagibina, \\ 344068, Rostov-on-Don, Russia \\ ${ }^{3}$ Technical University in Taganrog, 44, Nekrasovskii per., 347928, Taganrog, Russia
}

\begin{abstract}
The aim of the research is methodology development of labor motivation of agricultural workers, based on a competitive approach modern methods of personalizing personnel management, which will increase the productivity of agricultural workers and the efficiency of production activities in the industry. The methodological basis of the study were the methods of summarization, grouping, comparison and generalization, which were used during the analysis of scientific literature. The method of research of labor relations was applied - questionnaires, analysis and synthesis methods while discussing research results. The developed methodology involves a wider range of instruments of material and non-material motivation of labor. Material motivation is expressed in an additional bonus to the salaries of winners in the competition in the profession. Non-material motivation is represented by traditional tools (the winner title, respect in the team) and new tools of motivation (recognition of the employee as a person, respect for his desires and needs). The proposed motivation system was adapted for the operating conditions of the agricultural organization Ankor LLC, the main positions of the new system for motivating and stimulating the work of employees, who directly ensure the output of agricultural products, of this organization have been developed.
\end{abstract}

\section{Introduction}

The need of improving methods of personnel motivation is generated by modern trends in the development of labor relations in agriculture. The shift of labour from agriculture tland industry to the service sector is noticed. This means that during the period under review, almost $20 \%$ of employees moved from agriculture and industry to the service sector [1]. In the concept of three waves, A. Toffler the structural changes in the economy were described, they were shown in the transition from agricultural to industrial and then - to the postindustrial/information society, which lead to a change in approaches to the management of organization, including use of labor. Production conditions are changing, which are accompanied by increased flexibility in the use of workers' labor under the influence of

* Corresponding author: gaponenko.t@mail.ru 
changes in generally accepted forms of employment [2,3]. Nowadays, not only employers, but also employees are interested in changing labor relations, who increasingly prefer flexible working conditions that allow them to manage independently not only personal, but also working time. As J. Min and others notice [4], that we need to establish new concepts of decent work to cope with the issues in the fourth industrial revolution era.

The evolution of values, that determine people's preferences and priorities, presented in the work of A. Hines, a Professor at the University of Houston (USA) [5], allows us to see a trend in shifting the preference for material values to a greater priority of free time which is spent in search of pleasure from life and communication. Researcher R. Inglehart notes that "the value system and behavior of people depends on how guaranteed their survival is" [6]. A. Hines defines the latest change in the system of values as follows:" practical and functional approaches that are most appropriate in this particular situation come to the foreground" [5]. This means conversion to more flexible forms of employment, aspiration for a life, in which work and material rewards no longer play a Central role. In the field of staff management, it is reflected in the fact that motivating factors are complemented by the new connected with the ability of employees to determine the intensity and time of its work independently, to choose the form of material and non-material rewards (bonuses, extra day off, award, education opportunity, etc.) [7-9]. All this can be defined as a tendency to personalize labor relations, including in the field of labor motivation.

The realization of these tendencies in agricultural production should take into account its specific features that determine the peculiarities of motivation of agricultural workers:

- high dependence of productivity on natural and climatic conditions means instability of employment and earnings, and this is a big problem not only in material terms, but also in terms of the organization of free time, a sense of pleasure from life [10];

- love for the earth, nature, and animals are important non-material motivating factors of work [11];

- the low degree of automation and mechanization of agricultural labor, which is typical for Russia, forces workers to work hard, they work in uncomfortable working conditions, which undermines the desire to work;

- the tendency of the market to perfect competition due to the uniformity of the product and its many producers means that the product is not unique, which means that employees are motivated by the quantity, not the quality of the product.

In agriculture, the importance of social infrastructure, that affects the decision of an employee to stay in rural areas, is increased. However, present days, the following negative trends are occurred in Russia, that affect the factors of non-material motivation:

- the provision of pre-school and school facilities for children in rural areas is being reduced, as well as number of rural schools. Lower technical equipment of rural schools leads to unequal conditions for obtaining quality education [12];

- the level of cultural services in the village is being reduced - reduction of libraries, rural clubs;

- the number of medical centers is decreasing, which leads to a decrease in the level of medical care and provision of rural residents

- the network of trade, catering and consumer services enterprises is being reduced. Residents of the village have to spend a lot of time and money on trips to the city to solve everyday difficulties.

The transformation of approaches to personnel management in the conditions of changing economic structure proves the need in developing personnel motivation systems. It is also important to take into account the industry specifics of labor relations. However, there are very few scientific studies in the sphere of labor motivation in agriculture that take into account new fundamental economic changes. The purpose of this article is to develop a system of motivation for agricultural workers, taking into account current trends in personnel 
management personalization. Due to the low level of salaries in agriculture, which is typical for Russia economics, the system of material stimulating for labor is the most motivating for employees to work effectively. In this regard, it is proposed to develop material ways to stimulate labor and improve the procedure for calculating and distributing the bonus part of salary.

\section{Materials and methods}

One of the most effective ways of motivation of labor in agriculture, known since the times of the Soviet Union, is a competition. In the USSR, socialist competitions were common in those professions where you can clearly see the result of an employee, a community or a crew. In addition, in agriculture, competitions for the title of the best in their profession were spread, for example, the best tractor driver, machine operator, combine operator, milkmaid, and Stockman. This helps labor productivity to grow. It is proposed to develop the practice of a competitive approach taking into account modern methods of staff management personalization, which is expressed in the development of a system agricultural workers motivation based on a competitive approach.

Personalization of staff management, as a new method of personnel management, means taking into account the individual motives and needs of each employee while selecting a tool and method of motivating his work. Nowadays, during developing systems of labor motivation, they focus on general needs and motives, so they develop systems of motivation and stimulation of labor that are focused on the average employee [13]. However, every employee is a unique persona; he may have his own motives for choosing this profession, work in this team. As indicated in [11], «individual motivation is the result of collective societal pathways that generate particular opportunities and constraints, as well as guiding ideas and habits that 'work' within these pathways». That is why, in order for personnel management to be as effective as possible, it is necessary to look for individual motives of each employee and develop not general, but personalized systems of labor motivation $[14,15]$. Personalization of staff motivation management is expressed in the fact that each employee chooses his own form of bonus. Therefore, if an agricultural worker wins the competition for the best in his profession, he can choose what he wants to get - monetary compensation, farm products in the form of milk, meat or flour, or compensation for certain expenses. For example, for rural workers, natural payments or compensation for expenses, such as kindergarten fees, may be more important than cash payments.

Personal motives are determined based on the results of the survey. The developed form of the questionnaire is shown in Figure 1. 


\section{QUESTIONNAIRE FOR IDENTIFYING PERSONAL MOTIVES AND NEEDS OF AGRICULTURAL WORKERS}

1. Surname, first name, patronymic

2. Position

3. Education

4. Age, gender

5. Work experience at the company

6. Evaluate the importance of each motivational factor in descending order of importance (the first place - the most important factor, then descending)

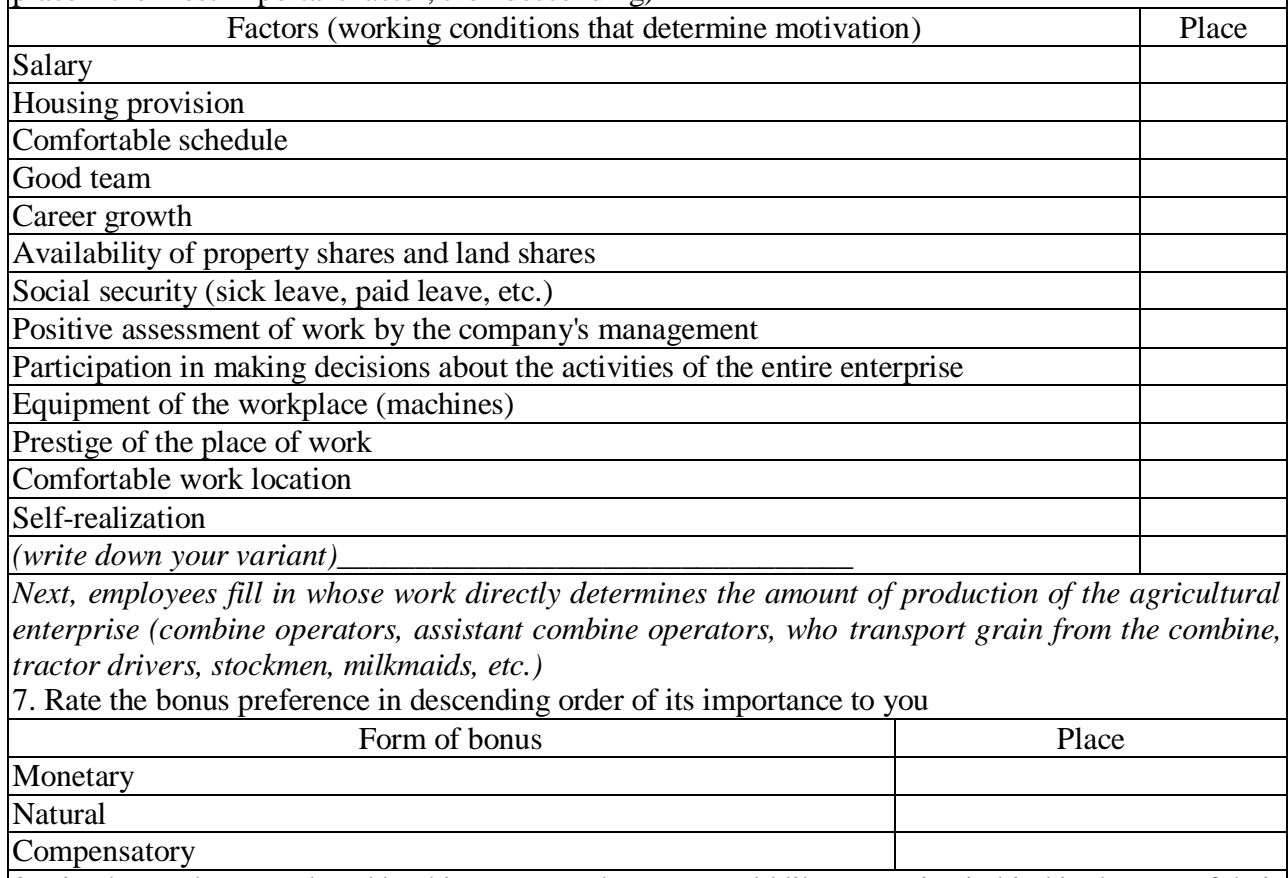

8. List the products produced by this company that you would like to receive in kind in the cost of their production, in descending order of importance (the first indicates the most necessary product for You, then-less significant)

\begin{tabular}{|c|c|}
\hline Provide the name of products & Place \\
\hline & 1 \\
\hline & 2 \\
\hline W & 3 \\
\hline
\end{tabular}

9. What kind of compensation would you like to receive (compensation for expenses for kindergarten, Internet, utilities, etc.)?

\begin{tabular}{|c|c|}
\hline Provide the name of services & Place \\
\hline & 1 \\
\hline & 2 \\
\hline
\end{tabular}

Fig. 1. Questionnaire for identifying personal motives of agricultural workers.

This developed questionnaire allows you to identify motivating factors and take into account the personal priorities of agricultural workers while forming a system of financial incentives for the organization. 


\section{Results}

The development of material ways to stimulate labor in agriculture is proposed on the basis of improving the procedure for calculating and distributing the premium part of the salary. It is proposed to introduce an approach to the construction and implementation of a system of labor motivation in agricultural enterprises, based on a competitive method of motivation, taking into account modern methods of personification of personnel management. The essence of the proposed method of labor motivation, based on a competitive approach, is as follows:

- a survey of employees of the agricultural enterprise is conducted, and their needs and incentives to work are identified;

- the production standards, that are mandatory for all employees of a certain profession, team or other group of workers, are determined;

- the procedure for identifying winners in the competition for each of the professions or in each group (team) that will receive additional bonuses is determined. The form of bonuses is determined based on the results of the survey. If the number of candidates for leadership exceeds 5-6 people, it is advisable to set 2-3 prize places in order to increase the chances of each employee receiving a bonus and maintain the spirit of competition;

- the procedure for the formation and distribution of the salary Fund between members of the group or employees of the same profession is being developed, taking into account the main part (salary), the bonus part and additional bonuses distributed taking into account personal preferences;

- at the end of the competition period, the winners have the opportunity to choose the form for receiving additional bonuses, taking into account their personal preferences. In this case, additional ranking of options for choosing the form of a bonus is possible (for example, only the winner can do this);

- employees, who have shown the worst results, may be sanctioned for passivity. This can be different forms of public criticism or funny titles, for example, "the slowest combiner".

\section{Discussion of the results}

The implementation of the proposed method is considered on the example of the agricultural enterprise Ankor LLC. It is located in the Peschanokopsky district of the Rostov region. Its main activity is the production of flour, milk and meat. The analysis showed that the company does not pay attention to motivation and stimulation of labor. All employees except two cleaners have the same bonus percentages. This does not encourage employees to work better.

To identify motivating factors, all employees of Ankor LLC were given questionnaires in the form provided earlier in fig.1. 60 questionnaires were distributed, and 55 questionnaires were returned filled out. The results after processing the questionnaires are presented in table 1.

Table 1. Results of the analysis of labor motivation factors at LLC "ANKOR" based on the results of the survey.

\begin{tabular}{|l|c|c|}
\hline \multicolumn{1}{|c|}{ Factors of motivation } & $\begin{array}{c}\text { The amount } \\
\text { of places }\end{array}$ & Grade \\
\hline Salary & 100 & 1 \\
\hline Housing provision & 368 & 6 \\
\hline Comfortable schedule & 312 & 3 \\
\hline Good team & 485 & 9 \\
\hline Career growth & 520 & 11 \\
\hline Availability of property shares and land shares & 384 & 8 \\
\hline
\end{tabular}




\begin{tabular}{|l|c|c|}
\hline Social security (sick leave, paid leave, etc.) & 130 & 2 \\
\hline Positive assessment of work by the company's management & 350 & 4 \\
\hline $\begin{array}{l}\text { Participation in making decisions about the activities of the entire } \\
\text { enterprise }\end{array}$ & 550 & 12 \\
\hline Equipment of the workplace (machines) & 355 & 5 \\
\hline Prestige of the place of work & 510 & 10 \\
\hline Comfortable work location & 374 & 7 \\
\hline Self-realization & 567 & 13 \\
\hline
\end{tabular}

The analysis of motivational factors of work of employees of Ankor LLC on the sum of the revealed places revealed the following:

- the two most important motivating factors for employees are salary and social security in the form of payment of sick leave, state benefits, and paid leave;

- further, such motivating factors as a convenient schedule and location of work, a positive assessment by the company's management, the provision of housing, the presence of a property share or land share (not all employees have it);

- the third group is formed by factors that poorly motivate employees of Ankor LLC - a good team, prestige of work, career growth, participation in decision-making about the company's activities, self-realization.

Thus, employees of Ankor LLC demonstrate a passive attitude to issues of personal and professional growth, building relations in the team. They are more important to material and social working conditions, convenient work schedule, but it is also important to recognize the leadership.

Participants of the competition for the best in the profession were also asked to choose the form of bonus (monetary, natural, compensation), types of products in kind and types of desired compensation. Based on the results of the survey, a database of personal motives and incentives for employees was created. The main provisions of the new system of motivation and incentives for certain categories of employees of Ankor LLC are presented in table 2.

Table 2. Main provisions of the new system of motivation and labor incentives for certain categories of employees of Ankor LLC.

\begin{tabular}{|c|c|}
\hline System parameter & Characteristic \\
\hline $\begin{array}{l}\text { The need in developing } \\
\text { a motivation system }\end{array}$ & Growing demand for dairy products, flour \\
\hline $\begin{array}{l}\text { Goals and tasks of the } \\
\text { development of the } \\
\text { labor motivation system }\end{array}$ & $\begin{array}{l}\text { The goal is to increase the company's profit and market share. Tasks: } \\
\text { - increase in production volumes } \\
\text { - maintaining high product quality } \\
\text { - reduced staff turnover } \\
\text { - formation of a stable professional team }\end{array}$ \\
\hline $\begin{array}{l}\text { Criteria for evaluating } \\
\text { the implementation of } \\
\text { the motivation system }\end{array}$ & $\begin{array}{ll}1 . & \text { Output growth } \\
2 . & \text { Profit growth } \\
3 . & \text { Production profitability growth }\end{array}$ \\
\hline $\begin{array}{l}\begin{array}{l}\text { Validity of the new } \\
\text { system }\end{array} \\
\end{array}$ & $\begin{array}{l}\text { One year with the subsequent continuation of the application of the system if } \\
\text { the goal of its implementation is achieved }\end{array}$ \\
\hline Questionnaire survey & $\begin{array}{l}\text { Once a year, a new employee fills out a questionnaire when he applies for a } \\
\text { job }\end{array}$ \\
\hline $\begin{array}{l}\text { Competition } \\
\text { participants }\end{array}$ & Milkers, calves, stockmen, mill workers \\
\hline $\begin{array}{l}\text { The period of the } \\
\text { competition }\end{array}$ & Every month \\
\hline $\begin{array}{l}\text { Procedure for } \\
\text { identifying winners }\end{array}$ & $\begin{array}{l}\text { According to the results of accounting for milk yield, the increase in live } \\
\text { weight of livestock, the volume of ground flour: } 1 \text { place - with the highest } \\
\text { indicator, then-in descending order of the result }\end{array}$ \\
\hline
\end{tabular}


\begin{tabular}{l|l|l|}
\hline $\begin{array}{l}\text { Procedure for forming } \\
\text { the salary Fund }\end{array}$ & $\begin{array}{l}\text { The main part is the salary for meeting the production rate of the required } \\
\text { quality. Bonus part }-10 \% \text { of the salary in the absence of labor violations }\end{array}$ \\
\hline Proceluse for &
\end{tabular} Procedure for forming Additional piece rate that form the bonus (prize) Fund are determined by the the bonus (prize) Fund total output (by the norm and above the norm). Four bonus (prize) funds are formed for each profession.

Distribution of the At the end of the quarter, the winner of each procession receives 50\% of the bonus (prize) Fund bonus (prize) Fund of this profession. The remaining prize pool is divided among the participants. In a team of three people: for the 2 nd place $-30 \%$ of the Fund, for the 3rd place-20\% of the Fund. In a group of 4-5 people: $25 \%$ for second place, the remaining part is divided equally between the other participants.

Personalization of the If the employee expressed a wish to receive a bonus in kind during the survey, form of a bonus (prize) then the desired products produced by the farm are given to him at the cost of its production

Evaluating the Once a quarter by comparing quarterly data with data for the same period last effectiveness of the year. Final performance assessment - after summing up the annual results of implementation of the the company

labor motivation system

Taking into account the share of flour, milk and meat produced in the income structure of Ankor LLC, we can expect that the introduction of the proposed system of labor motivation, based on a competitive approach, will increase the company's revenue by $6.7 \%$. After the introduction of a new incentive system based on a competitive approach in the conditions of Ankor LLC, the cost of production will grow at a slower pace, since with a slight increase in labor costs, there will be an increase in labor productivity in professions that give the main $(70 \%)$ output of the enterprise's products.

For employees, it was concluded that if their output increases by $10 \%$, only the winners of the competition will benefit from this under the proposed wage system, since they will receive more wages than in the basic version, and the rest will receive less. If production volumes increase by $20 \%$, all categories of employees will receive more, while the pay of the winners will increase by $26-36 \%$, and the losers will either not change much, or will also increase slightly.

Total labor costs with a projected increase in the production of flour and milk by $10 \%$, meat by $7.7 \%$ is almost unchanged, an increase of only $0.73 \%$. But due to the competitive approach and better motivation of labor, the volume of production will increase. This will increase overall revenue, the overall productivity of the company by $6.7 \%$, and reduce the salary intensity of products.

The lead rate is higher than 1 . This suggests that the increase in labor productivity is much faster than the increase in the wage Fund, and means the effectiveness of the implementation of the developed system of motivation.

\section{Conclusion}

This article develops a method for motivating agricultural workers based on current trends in the sphere of personnel management, which are expressed in the personalization of the staff motivation system. Its implementation will increase the productivity of agricultural workers and, in general, efficiency of production activities. The proposed method is characterized by an orderly and systematic idea of how, in what sequence, the process of improving the system of labor motivation should take place, taking into account modern trends in personalization of staff management. Practical testing of the developed method was carried out and positive estimates of the dynamics of economic indicators of the agricultural enterprise expected as a result of its implementation were obtained. 


\section{References}

1. K. Barmuta, A. Borisova, M. Glyzina, Mediterranean Journal of Social Sciences 6 (3S4), 91-96 (2015) doi: 10.5901/mjss.2015.v6n3s4p91

2. R. Savkina, E. Udovik, G. Murzagalina, L. Orekhova, N. Lipchiu, Espacios 31, 4 (2018)

3. J. Westerman, Social Science Research 76, 169-185 (2018) doi: 10.1016/j.ssresearch.2018.08.007

4. J. Min, Y. Kim, S. Lee, T.-W. Jang, I. Kim, J. Song, Safety and Health at Work 10(I.4), 400-408 (2019) doi: 10.1016/j.shaw.2019.09.005

5. A. Hines, Foresight and STI Governance 13(1), 19-30 (2019) doi: 10.17323/25002597.2019.1.19.30

6. R. Inglehart, Cultural Evolution (Cambridge University Press., Cambridge, 2018)

7. B. Lalani, P. Dorward, G.Holloway, E. Wauters, Agricultural Systems 146, 80-90 (2016) doi: 10.1016/j.agsy.2016.04.002

8. M. Kriklivaya, O. Grishchenko, M. Glyzina, Z. Gukasyan, International Journal of Applied Business And Economic Research 15(24), 272-279 (2017)

9. G. Standing, A precariat charter: From denizens to citizens (Bloomsbury Publishing, New York, 2014)

10. K. Jones, D. Tobin, Current Opinion in Environmental Sustainability 35, 69-74 (2018) doi:10.1016/j.cosust.2018.11.001

11. G. Van Hecken, P. Merlet, M. Lindtner, J. Bastiaensen, Ecological Economics 156, 519529 (2019) doi:10.1016/j.ecolecon.2016.12.030

12. Z. Bednaříková, M. Bavorová, E. Ponkina, Journal of Rural Studies 45, 99-111 (2016) doi: 10.1016/j.jrurstud.2016.03.006

13. A. Gridchina, L. Orekhova, S. Lyubimtseva, N. Yakovenko, I. Komov, International Journal of Economics and Financial Issues 6(S8), 54-59 (2016)

14. P. Mattsson, Economic Analysis and Policy 62, 325-341 (2019) doi: 10.1016/j.eap.2018.09.007

15. M. Haylock, P. Kampkötter, Data in Brief 27, 104824 (2019) doi: 10.1016/j.dib.2019.104824 